\title{
State control (supervision) over the quality and safety of agricultural products (on the example of the Sverdlovsk region)
}

\author{
Dmitry Bagretsov ${ }^{1, *}$, Boris Voronin ${ }^{2}$, Elena Chebykina $^{3}$ \\ ${ }^{1}$ Ural Institute of Management - branch of RANEPA, Russia, Yekaterinburg \\ ${ }^{2}$ Ural State Agrarian University, Russia, Yekaterinburg \\ ${ }^{3}$ Ural State Law University, Russia, Yekaterinburg
}

\begin{abstract}
The Federal Service for Veterinary and Phytosanitary Surveillance (Rosselkhoznadzor), located in the structure of the Ministry of Agriculture of the Russian Federation, implements control and supervisory activities by a specially authorized state authority in the field of quality and safety of agricultural products, raw materials and food, checks legal entities and individual entrepreneurs in the implementation of their activities, compliance with its requirements, established by federal laws and other regulatory legal acts of the state executive authority in this area. Structural divisions of the Rosselkhoznadzor, for example, the Rosselkhoznadzor Administration for the Sverdlovsk Region, exist in the constituent entities of the Russian Federation. Specialists of this structure carry out functional control and supervisory measures to ensure the quality and safety of agricultural products produced in the Sverdlovsk Region and imported from other regions of the Russian Federation and abroad. Legal regulation of relations in this area is carried out by federal laws, resolutions of the Government of the Russian Federation and other regulatory legal acts that differentially regulate certain areas in the field of quality and safety of agricultural raw materials of plant and animal origin.
\end{abstract}

\section{Introduction}

Control and supervisory activities objectively contribute to improving the efficiency of the Rosselkhoznadzor in the field of quality and safety of agricultural raw materials and food in the context of modern transformations in the agricultural sector of the economy, despite the tendency to reduce administrative impact. Therefore, the topic of the article is relevant. There are federal laws that regulate the above-mentioned relations in a unified manner. We can single out federal laws among such legislative acts: "On the development of Agriculture" [1], "On the Quality and safety of food Products" [2], "On Technical Regulation" [3], "On Veterinary Medicine" [4], "On Plant Quarantine" [5], "On State Control over the Rational Use of Grain and its Processed Products" [6], "On Environmental Protection" [7], the Code of Administrative Offences of the Russian Federation [8]. The

\footnotetext{
* Corresponding author: bagretsow75@ya.ru
} 
problems of state control and supervision over the quality and safety of agricultural products, raw materials and food are investigated in many scientific papers that are published in scientific journals, monographs. Dissertations of Candidate of Sciences and Doctor of Sciences are defended on this topic. Let us note some scientific publications of Ural scientists: B.A. Voronin, I.A. Tukhbatov, Ya.V. Voronina "Law enforcement practice of Rosselkhoznadzor in the field of veterinary medicine (review of the subjects of the Russian Federation)" [9], B.A. Voronin, O.G. Loretz, I.A. Tukhbatov "Issues of improving state control (supervision) in agriculture (on the example of the Sverdlovsk region)" [10], B.A. Voronin, A.G. Svetlakov, Ya.V. Voronina "On improving state control in the field of agricultural consumer cooperatives and other small forms of management in the agroindustrial complex" [11].

At the same time, the topic of state control (supervision) in agriculture is of scientific interest. The scientific novelty of the research topic lies in the analysis of the activities of the Rosselkhoznadzor system in cooperation with the state land supervision, municipal land control, state environmental supervision and other organizations that monitor the quality and safety of food products.

The purpose of the research of the topic of the scientific article is to identify the completeness and quality of legal regulation of control and supervisory activities in agriculture.

The objectives of the study are to analyze the effectiveness of the work of control and supervisory authorities to identify violations of legislation in the field of quality and safety of agricultural products, raw materials and food produced in the territory of the Sverdlovsk region and imported from other subjects of the Russian Federation and imported.

The theoretical significance of this scientific article lies in the increment of knowledge in the science of public administration and state control, as well as in agrarian and legal science.

The practical significance of this work is characterized by the possibility of using the research material in the educational process in institutions of agricultural education and in management activities in agriculture.

Methods for researching the topic of this article: analysis, synthesis, generalization, economic-legal, sociological methods.

\section{Research results}

The production of agricultural products and agricultural raw materials for obtaining food products is a decisive factor in ensuring the food security of the state. Ensuring the quality and safety of agricultural products should be no less important condition. The control and supervisory authorities are called upon to monitor the conditions of production activities in this area and the observance of sanitary-epidemiological, environmental and other legislative requirements by agricultural producers. The Federal Service for Veterinary and Phytosanitary Supervision (Rosselkhoznadzor) of the Ministry of Agriculture of Russia performs the main functions in this area.

Veterinary supervision in the field of import of livestock products and live animals to the territory of the Sverdlovsk region and export of livestock products and live animals from the Sverdlovsk region is the activity of the Rosselkhoznadzor, for example, in the Sverdlovsk region. Control over the registration of veterinary documents is carried out in the "Argus" GIS system and in the "Mercury" system. Monitoring of import and export of products subject to Veterinary supervision is carried out at the Koltsovo airport, on the railway and border posts on highways.

Violations of veterinary legislation are detected annually in the course of control and supervisory measures in the field of veterinary supervision in terms of the quality and 
safety of livestock products due to non-compliance with production technologies, expired expiration dates and other factors, which excludes the sale of such products to the public.

Epizootic monitoring for the detection and prevention of infectious diseases of animals and transmitted to humans (anthrax, African swine fever (ASF), modular dermatitis, footand-mouth disease) is carried out systematically. The infectious disease rabies remains one of the serious problems for the Sverdlovsk region.

Analysis of the epizootic situation of rabies indicates the presence of natural foci of this infection on the territory of the Sverdlovsk region (Irbitsky, Talitsky, Kamensky, Pyshminsky municipal districts and urban districts). Rabies cases were detected in other areas of the region.

Special control is carried out over the condition of places for the emergency destruction of animal corpses (carcasses) in the event of a possible occurrence of African swine fever. There were 397 such places in the region in 2016, there are 24 biothermal pits, one recycling plant, 45 incinerators.

Veterinary supervision specialists monitor brucellosis and leukemia in farm animals as part of monitoring. Diseases of fish (especially carp) are detected. The places of storage and sale of agricultural products are regularly checked with their entry and registration in the GIS "Cerberus".

According to the results of the conducted studies, samples of products are identified, sometimes not meeting the safety requirements for microbiological indicators. Thus, the presence of listeria, salmonella, mold, yeast, Staphylococcus aureus and other harmful substances that are found in meat and meat products, milk and dairy products, preserves, frozen fish, chilled fish is detected.

Recently, cases of the presence of antibiotics in products (semi-finished meat products, raw milk, yogurt, butter and others) have been identified. The regime of enhanced laboratory control and liability measures are applied at all enterprises where livestock products are detected that do not meet the requirements of the legislation of the Russian Federation (according to microbiological and toxico-chemical indicators).

The Management staff controls the turnover of feed and feed additives. Samples are sent for chemical and toxicological studies, including for the presence of genetically modified organisms (GMOs). The GMO Center was established on the basis of the Federal State Budgetary Institution "Sverdlovsk Reference Center of Rosselkhoznadzor" in the territory of the Sverdlovsk region.

Serious attention is paid to the identification of cases of falsification of livestock products, as there are facts of falsification of products produced in the Sverdlovsk region and imported from other regions of the Russian Federation.

Specialists of the "Sverdlovsk Reference Center of Rosselkhoznadzor" conduct testing of food products and food raw materials, feed and feed additives in accordance with GOST and technical specifications, for compliance with the SanPiN and standards that establish quality and safety criteria for humans. The information is sent to retail chains, Rospotrebnadzor, territorial administrations of Rosselkhoznadzor, placed in the CYRANO system.

Inspections on compliance with licensing requirements, on applications for granting or reissuing licenses for pharmaceutical activities in the retail trade of medicines for veterinary use are carried out during the implementation of pharmacovigilance. Medicines that are not suitable for further use in veterinary medicine are withdrawn and disposed of as a result of inspections.

Quarantine phytosanitary control is the most important direction in the activity of the Rosselkhoznadzor. Significant batches of quarantined products are certified in a year with registration in the Argus-phyto system. Phytosanitary control is carried out at checkpoints across the state border, in relation to sanctioned products in order to prevent them from 
entering circulation on the territory of the Sverdlovsk region. Phytosanitary monitoring is carried out in specially protected natural territories of federal and regional significance. According to the results of quarantine measures in the territory of the Sverdlovsk region, quarantine is imposed, for example, on the western (California) flower thrips, as well as on the golden potato nematode. Golden potato nematode is a microscopic worm that parasitizes the roots of potatoes and other nightshade crops (tomato, eggplant, henbane, black nightshade, bittersweet, etc.) and is a dangerous pathogen of potato disease globoderosis. The yield of commercial potato tubers can decrease from $30 \%$ to $80 \%$ with severe plant damage.

The largest areas of potato plantings, where the golden potato nematode was detected, were found in the Sverdlovsk region: in Krasnoufimsky, Kamensky, Sysertsky, Beloyarsk, Pyshminsky urban districts, as well as in the cities of Yekaterinburg, Nizhny Tagil, Pervouralsk, Revda [12].

In the Russian Federation, there was no special state authority exercising control and supervisory functions in the field of grain quality and products of its processing, due to the abolition of the State Grain Inspection in December 2004. The Rosselkhoznadzor carried out part of the measures in this area, but finally the state control (supervision) over the quality and safety of grain and its processed products was transferred to it in 2013 [13], when it was necessary to monitor compliance with the requirements of the technical regulations of the Customs Union "On Grain Safety" [14].

The register of agricultural producers engaged in the production, use, part-time work, import, sale and storage of seeds of agricultural plants on the territory of the Sverdlovsk region takes into account over 900 subjects of various organizational and legal forms of management.

Inspections reveal frequent violations:

1) absence of declarations of conformity for grain put into circulation on the territory of the Customs Union,

2) purchase of cereals that do not meet the requirements of national standards for safety and quality,

3) lack of consumer labeling,

4) lack of accompanying documents confirming the safety and quality of cereals, which are an integral part of the terms of government contracts.

Inspection of budgetary institutions is important from the point of view of ensuring food security. In recent years, food products that do not meet the requirements of regulatory documents are often found in these structures during control checks. These are cereals with a moldy odor and a specific taste, infected and contaminated with the larvae of grain pests, with an excess of the content of metal-magnetic impurities and spoiled kernels. And these are just a few examples when food safety standards are clearly violated due to the lack of proper production control within the organization.

The transfer of functions for the implementation of the state land supervision of the Rosselkhoznadzor made it possible to more actively identify violations of legislation in the field of rational use of agricultural land. The involvement of unused land plots in agricultural turnover is of urgent importance, which is necessary to expand the acreage for the cultivation of grain and vegetable crops.

Specialists of the Rosselkhoznadzor Administration for the Sverdlovsk Region carried out 996 control and supervisory activities, including 75 raids, 177 administrative inspections / investigations, took part in 27 joint inspections in 2020. Experts identified 779 violations of the requirements of the legislation of the Russian Federation as a result of the control and supervisory measures taken. 426 persons were brought to administrative responsibility. The volume of inspected and inspected products amounted to more than 880 thousand tons. More than 10 thousand tons of products were identified that were in 
circulation in violation of the established requirements, of which 2.6 thousand tons of plant products and 74 thousand tons of livestock products. The following categories of agricultural products most often did not meet quality standards:

1. Dairy products - butter, cheese, kefir.

2. Meat products - canned food (semi-finished products) [15].

\section{Conclusion}

The Federal Service for Veterinary and Phytosanitary Surveillance (Rosselkhoznadzor), which is a state executive authority and is located in the structure of the Ministry of Agriculture of the Russian Federation, performs responsible tasks in the field of ensuring the production of high-quality and safe agricultural products, raw materials and food.

The Food Security Doctrine of the Russian Federation [16] defines the production of domestic agricultural products with a high level of quality and safety as the most important indicator.

Certain areas of the Rosselkhoznadzor's control and supervisory activities listed in the article carry out state control and supervision in cooperation with other state bodies, including in agriculture and in the food market, solve issues of ensuring the quality and safety of food.

Rosselkhoznadzor specialists should not go beyond the powers defined by the Federal Law "On the Protection of the Rights of Legal Entities and Individual Entrepreneurs in the Exercise of State Control (Supervision) and Municipal Control", performing their functions [17].

\section{References}

1. Federal Law, 264-FZ, 29.12.2006, Collected Legislation of the Russian Federation, 11 (I), 27 (2007)

2. Federal Law, 29-FZ, 02.01.2000, SZ RF, 2, 150 (2000)

3. Federal Law, 184-FZ, 27.11.2002, SZ RF, 52 (I), 5140 (2002)

4. Federal Law, 243-FZ, 13.07.2015, SZ RF (2015)

5. Federal Law, 206-FZ, 14.07.2014, SZ RF, 30, 4256 (2014)

6. Federal Law, 183-FZ, 05.12.1998, SZ RF, 49, 5970 (1998)

7. Federal Law, 7-FZ, 10.01.2002, SZ RF, 2, 133 (2002)

8. Federal Law, 195-FZ, 12.30.2001, SZ RF, 1 (I), 1 (2002)

9. B. A. Voronin, I. A. Tukhbatov, Ya. V. Voronin, Agrarian Bulletin of the Urals, 3, 11 (2018)

10. B. A. Voronin, O. G. Lorets, I. A. Tukhbatov, Agrarian Bulletin of the Urals, 4, 11 (2018)

11. B. A. Voronin, A. G. Svetlakov, Ya. V. Voronina, Agrarian Bulletin of the Urals, 7, 9 (2017)

12. L. Goreva, Niva Ural, 1, 10-11 (2017)

13. Decree of the Government of the Russian Federation № 553, 02.07.2013, Consultant Plus (2013)

14. Technical Regulations TR CU 015/2011 of the Customs Union "On grain safety", EA ES (2011)

15. Information from the Office of the Rosselkhoznadzor for the Sverdlovsk region (2021) 
16. Doctrine of food security of the Russian Federation, approved. by decree of the President of the Russian Federation No. 20 of 31.01.2020, SZ RF, 4, 345 (2020)

17. Federal Law, 294-FZ, 26.12.2008, SZ RF, 52 (I), 6249 (2008) 